\title{
P114: Gombe Hospital hand hygiene project
}

\author{
L Haruna \\ From 2nd International Conference on Prevention and Infection Control (ICPIC 2013) \\ Geneva, Switzerland. 25-28 June 2013
}

\section{Introduction}

Gombe Hospital is a 100-bed rural General public hospital situated $70 \mathrm{~km}$ west of Kampala, Butambala district in Uganda. Its catchment area is 300,000 people. The hospital staffing is $55 \%$ of the recommended. The hospital is facing a problem of inadequate water supply. This therefore made the observation of hand hygiene $(\mathrm{HH})$ as recommended by WHO very difficult for both healthcare workers $(\mathrm{HCW})$ and patients leading to high rates of healthcare-associated infections (HAI). Therefore a $\mathrm{HH}$ project was launched.

\section{Objectives}

To strengthen hospital infection control in the context of inadequate water supply.

\section{Methods}

Alcohol-based handrub (ABHR) were installed in wards and pocket size bottles were provided to HCWs, following training of all HCWs and how to use ABHR. HCWs were monitored for their compliance with the WHO " 5 moments of $\mathrm{HH}$ ” periodically and compliance rates calculated. The hospital also registered with WHO's Clean Care Safer Care campaign as part of its commitment to Patient Safety.

\section{Results}

HCWs' compliance with the WHO five moments increased from $31 \%$ to $69 \%$ within 6 months of project implementation reflecting a positive change in attitude of HCWs towards $\mathrm{HH}$. There was variation in compliance between departments and individual HCWs which was attributed to $\mathrm{HCW}$ attitudes, use of gloves, and time constraint. During a two weeks period when there was totally no water in the hospital operating theatre, ABHR was the only solution used for pre-operative scrubbing in 14 major operations and observed postoperative outcomes was the same as in the formal scrubbing when water and soap were used. Reduction in

\footnotetext{
Health, Gombe Hospital, Kampala, Uganda
}

(c) 2013 Haruna; licensee BioMed Central Ltd. This is an Open Access article distributed under the terms of the Creative Commons Attribution License (http://creativecommons.org/licenses/by/2.0), which permits unrestricted use, distribution, and reproduction in any medium, provided the original work is properly cited. sepsis cases in maternity ward and in cross infection of diarrhea cases among the children in pediatrics ward was observed, as well as reduction in duration of hospital stay. ABHR was used also regularly by attendants and patients on the wards contributing to the noted reduction in ward sepsis.

\section{Conclusion}

Compliance progressively improved over time which was an indication that HCWs owned the project and integrated the $5 \mathrm{WHO}$ moments of $\mathrm{HH}$ concept. In Uganda and countries where health facility infrastructure is usually poor including no access to clean water, ABHR has big potential to improve hygiene condition without minimal expenditure on infrastructure renovation.

\section{Disclosure of interest}

None declared.

Published: 20 June 2013

doi:10.1186/2047-2994-2-S1-P114

Cite this article as: Haruna: P114: Gombe Hospital hand hygiene project. Antimicrobial Resistance and Infection Control 2013 2(Suppl 1):P114.

Submit your next manuscript to BioMed Central and take full advantage of:

- Convenient online submission

- Thorough peer review

- No space constraints or color figure charges

- Immediate publication on acceptance

- Inclusion in PubMed, CAS, Scopus and Google Scholar

- Research which is freely available for redistribution 